\title{
Pemberdayaan Remaja Desa Tahunan Kecamatan Sale Kabupaten Rembang dengan Keterampilan Karawitan, Dalang dan Seni Tari Sebagai Upaya Mengurangi Angka Kemiskinan
}

\author{
Muhammad Tahwin, Dian Anita Sari \\ Sekolah Tinggi Ilmu Ekonomi YPPI Rembang \\ tahwinm@yahoo.co.id
}

Submitted: 12 January 2019. Revised: 8 July 2019. Accepted: 27 July 2019

Key word:

traditional arts;

karawitan;

traditional

dance; shadow

puppet;

assistance

\section{Abstract}

These community service activities are carried out in the Tahunan Village, Sale District, Rembang. The existence of arts groups in the village still requires assistance from human resource such as trainer. Therefore, this service aims to 1) strengthen the position of the arts group to be more empowered; 2) increasing the number of group members from young people; 3) improve the skills of group members in musical, orchestrating, and dancing; and 4) increase the income of group members. The method used in this community service program is training and mentoring. The results of this program are: 1) The arts group already has a name and routinely conducts meetings and training activities; 2) members of group from the school age and young adults are increasing; 3) the art group is known outside the Sale District and gets a performance offer.

\section{Abstrak}

Kata Kunci

kesenian tradisional; karawitan; tari tradisional; wayang kulit; pendampingan
Kegiatan pengabdian masyarakat ini dilakukan di Desa Tahunan, Kecamatan Sale, Rembang. Keberadaan kelompok kesenian yang ada di desa tersebut masih membutuhkan pendampingan dan bantuan sumber daya pelatih. Oleh karena itu, pengabdian ini bertujuan untuk 1) mengukuhkan posisi kelompok kesenian untuk lebih berdaya; 2) memperbanyak anggota kelompok yang berasal dari kaum muda; 3) meningkatkan keterampilan anggota kelompok dalam karawitan, mendalang, dan menari; dan 4) meningkatkan pendapatan anggota kelompok. Metode yang digunakan dalam program pengabdian masyarakat ini adalah pelatihan dan pendampingan. Hasil dari program ini adalah: 1) Kelompok kesenian sudah memiliki nama dan rutin melakukan kegiatan pertemuan dan latihan; 2) anggota dari kelompok usia sekolah dan dewasa muda meningkat; 3) kelompok kesenian dikenal ke luar Kecamatan Sale dan mendapatkan tawaran pementasan. 


\section{PENDAHULUAN}

Desa Tahunan adalah desa di Kecamatan Sale, Kabupaten Rembang, Jawa Tengah. Desa Tahunan di sebelah Utara berbatasan dengan Desa Gading dan Desa Tengger, sebelah Barat berbatasan dengan Desa Tegaldowo Kec. Gunem, sebelah Timur berbatasan dengan Desa Gading dan sebelah Selatan berbatasan dengan Kec. Bogorejo Kabupaten Blora. Desa berpenduduk 6.078 jiwa ini sebagian besar penduduknya (60\%) bermata pencaharian sebagai buruh tani. Desa ini juga merupakan desa yang menjadi fokus program pengentasan kemiskinan karena menurut pengelompokan rumah tangga dalam basis data terpadu, Desa Tahunan masuk dalam kelompok terendah. (Data Primer-Monografi Desa Tahunan, 2017)

Meskipun Desa Tahunan termasuk dalam desa terendah dalam pengelompokan rumah tangga, namun penduduk desa masih memiliki kesadaran yang cukup tinggi terhadap kesenian dan budaya daerah. Terbukti dari adanya pementasan kesenian pada acara sedekah bumi yang dilaksanakan setiap tahun dan jumlah kelompok kesenian di Desa Tahunan yang lebih banyak dibandingkan dengan desa lain (Rembang, 2015). Kelompok kesenian yang ada di Desa Tahunan 4 (empat) di antaranya adalah kelompok Karawitan. Kelompok- kelompok karawitan ini memulai kegiatannya pada tahun 1980. Potensi kelompok karawitan dapat diberdayakan mengingat seluruh desa di Kecamatan Sale melakukan ritual sedekah bumi setiap tahun dan keberadaan kelompok karawitan di desa lain di Kecamatan Sale tidak sebanyak di Desa Tahunan.

Kelompok karawitan yang menjadi mitra pengabdian sudah bisa memainkan instrument kendang ladrangan dan ciblon. Seiring dengan berkembangnya zaman. Anggota kelompok karawitan semakin berkurang. Saat ini kelompok hanya memiliki anggota sejumlah 15 (lima belas orang) dan sebagian besar anggotanya adalah kelompok golongan umur 35 tahun ke atas. Selain itu, keterbatasan sumber daya manusia yang memiliki kapasitas untuk melatih menjadikan kegiatan latihan semakin jarang. Penanggung jawab kelompok yang merupakan anggota sejak awal terbentuknya kelompok juga memiliki keterbatasan dalam pengembangan aransemen (garap) instrumen. Kondisi ini merupakan salah satu alasan diperlukannya pelatiha karawitan yang memiliki penguasaan dalam bidang lagu, aransemen, dan vokal.

Selain kelompok karawitan, di Desa Tahunan juga mempunyai potensi dibidang seni pedalangan. Hal ini dibuktikan dengan adanya seorang remaja 
yang memiliki potensi untuk menjadi dalang. Dalang wayang kulit remaja ini dilatih juga oleh anggota kelompok karawitan. Namun demikian, kemampuan dalang remaja ini kurang berkembang karena pelatih dalang memiliki kemampuan utama sebagai pengrawit, sehingga sangat terbatas dalam kemampuan suluk, ontowecono maupun sabet. Sehingga diperlukan pelatih dalang profesional yang mampu meningkatkan kemampuan dalang remaja di Desa Tahunan.

Karawitan dan wayang kulit memiliki hubungan yang sangat erat. Bahkan Karawitan memegang peranan penting dalam sebuah pergelaran wayang kulit. Pengrawit dan sinden tidak hanya sebagai pengiring pagelaran, tetapi memiliki peran penting menghidupkan suasana baik dalam adegan maupun karakterisasi tokoh (Sukistono, 2014). Ketiadaan pelatih yang betul-betul mengerti tentang garap karawitan adalah faktor penting yang menjadikan instrumen yang digarap oleh Kelompok karawitan belum mengarah sebagai pengiring pementasan wayang kulit.

Kurang berkembangnya kelompok karawitan juga disebabkan belum adanya organisasi yang membina. Ketiadaan organisasi ini membuat kegiatan yang dilaksanakan oleh kelompok karawitan bersifat insendentil. Kondisi ini bisa dilihat dari rutinitas latihan yaitu apabila ingin latihan maka kelompok menjadwalkan latihan, tetapi apabila anggota tidak menginginkan latihan maka latihan ditiadakan. Demikian juga dengan latihan dalang yang dilaksanakan secara personal tanpa adanya penjadwalan yang jelas.

Pengembangaan kelompok karawitan dilakukan dengan membentuk organisasi yang menaungi juga perlunya pemberdayaan pemuda dan remaja desa sebagai penggerak kesenian di Desa Tahunan. Aset sebuah desa untuk dapat meningkatkan potensi pariwisatantanya adalah remaja berusia SMP, SMA, atau lulusan keduanya sebagaimana yang diberdayakan untuk mewujudkan desa wisata (Egar, Fahmi, Yulianti, \& Musarokah, 2017). Anggota kelompok kesenian mitra masih banyak yang sudah berusia dewasa akhir, sehingga penambahan annggota berusia remaja dan dewasa muda sangat dibutuhkan terutama untuk tujuan nguri-uri (melestarikan) budaya asli Desa Tahunan.

Kondisi jumlah anggota yang masih sedikit (20 orang) dan belum adanya jadwal latihan rutin menjadikan daya jual kelompok kesenian mitra untuk bisa mendapatkan undangan pementasan masih rendah dan ini berakibat pada tidak adanya tambahan penghasilan anggota kelompok 
kesenian yang berasal dari potensi kesenian yang dimiliki.

Berdasarkan kondisi-kondisi ini, tujuan pengabdian yang dilakukan adalah 1) mengukuhkan posisi kelompok kesenian untuk lebih berdaya; 2) memperbanyak anggota kelompok yang berasal dari kaum muda; 3) meningkatkan keterampilan anggota kelompok dalam karawitan, mendalang, dan menari; dan 4) meningkatkan pendapatan anggota kelompok. Fokus pelaksanaan pengabdian adalah untuk membentuk dan mengukuhkan kelompok kesenian dalam bentuk sanggar atau paguyuban, melatih karawitan dengan hasanah tembang yang lebih luas, melatih dan mendampingi dalang cilik dalam suluk, ontowecono maupun sabet, serta melatih anak usia dini dalam menari klasik. Hal ini dilakukan dengan harapan pada saat mereka dewasa akan mampu mengembangkan budaya seni tersebut (Susilo dkk., t.t.)

\section{METODE}

Berdasar pada situasi umum wilayah dan potensi yang ada, serta masih banyaknya kendala yang dihadapi oleh kelompok karawitan dan dalang Desa Tahunan, maka melalui program pengabdian pada masyarakat STIE YPPI Rembang ini akan membantu menyelesaikan masalah yang ada pada masyarakat seni Desa Tahunan Pembentukan Sanggar Budaya akan meningkatkan ketertiban administrasi dan rutinitas latihan sehingga akan tercipta pembinaan secara berkelanjutan, hal ini dimaksudkan karena adanya keinginan anggota kelompok karawitan dan masyarakat pendukung untuk senantiasa dapat meningkatkan apa yang telah dicapai dapat diandalkan dalam berbagai aktivitas yang melibatkannya. Sehingga dengan potensi yang dimiliki serta adanya dukungan dari masyarakat, kelompok karawitan dapat mengembangkan diri dengan berbagai hal yang ada kaitannya pertunjukan wayang kulit dan seni tari.

Pelatihan karawitan secara tertib dan rutin dengan pelatih profesional akan meningkatkan kemampuan pengrawit baik secara teknis maupun kemahiran dalam gending-gending garap dalam mengiringi pentas wayang kulit. Pelatihan terhadap dalang remaja akan semakin meningkatkan kemampuannya baik dalam hal suluk, ontowecono maupun sabet. Demikian juga dengan pelatihan tari yang dilaksanakan terhadap anak-anak dimaksudkan untuk menanamkan kecintaan pada budaya seni sejak usia dini. Hal ini dilakukan dengan harapan pada saat mereka dewasa akan mampu mengembangkan budaya seni tersebut. 
Berdasarkan potensi dan permasalahan bidang kesenian yang ada di Desa Tahunan, maka metode pelaksanaan Program Pengabdian Kepada Masyarakat ini adalah dengan melakukan pelatihan dan pendampingan. Secara umum implementasinya adalah sebagai berikut:

1. Pembentukan Sanggar Budaya

Pembentukan sanggar budaya dimaksudkan sebagai organisasi yang menaungi dan melakukan pembinaan terhadap kegiatan kesenian di Desa Tahunan. Dengan adanya sanggar budaya akan tercipta ketertiban administrasi karena adanya organisasi yang mengelola kegiatan. Selain itu dengan adanya sanggar budaya dapat meningkatkan kontinuitas pelaksanaan kegiatan kesenian di Desa Tahunan.

2. Pelatihan

Kegiatan Pengabdian Pada Masyarakat yang berupa pelatihan karawitan, pedalangan dan seni tari ini dirancang untuk dilaksanakan di Desa Tahunan Kecamatan Sale dengan sasaran utama adalah kelompok karawitan, dalang remaja dan anak-anak usia dini. Metode yang akan digunakan dalam pelatihan ini adalah dengan cara trainer participation. Metode ini mencakup cara seorang tutor menularkan pengetahuan dan keterampilan seni karawitan, pedalangan dan seni tari.
Metode pelatihan yang digunakan ketiga pelatih untuk mengukur tingkat pemahaman dan keterampilan dari peserta drill, demonstrasi, dan dialog/ tanya jawab/ diskusi.

a. Pelatihan Karawitan

Pelatih karawitan yang dipilih dalam program pengabdian adalah seorang menjadi musisi Gamelan. Pelatih ini sudah terbiasa melatih dan dapat memberikan contoh yang baik dalam praktik dan membaur akrab dengan para anggota yang mengikuti latihan karawitan. Pelatih melakukan pendekatan personal diutamakan supaya materi cepat diserap oleh peserta pelatihan. Materi yang diajarkan adalah gending-gending untuk mengiringi pementasan wayang kulit maupun tari.

b. Pedalangan

Pelatih dalang yang dipilih dalam program pengabdian merupakan dalang profesional. Sehingga dapat memberikan contoh yang baik atau melakukan praktik mendalang serta dekat dengan peserta agar dapat diketahui apakah peserta latihan memahami materi yang diberikan. Pelatih juga memberikan referensi cerita wayang kulit kepada dalang muda. Materi pelatihan yang digunakan adalah pemahaman 
terhadap alur lakon, suluk, ontowecono dan sabet.

c. Seni Tari

Pelatih tari merupakan penari profesional. Sebagai penari profesional harus dapat memberikan contoh yang baik dalam praktik dan membaur akrab dengan peserta yang mengikuti latihan. Pendekatan personal diutamakan supaya materi cepat diserap oleh peserta pelatihan. Materi pelatihan yang digunakan terbatas pada tari anak-anak, seperti tari bondan serta tari gambyong.

3. Kegiatan Pendampingan.

Kegiatan pendampingan yang dilakukan dalam implementasi kelompok karawitan, dalang remaja dan seni tari di Desa Tahunan, dilakukan dengan tujuan untuk mendampingi, agar mampu meningkatkan ketrampilan dan selanjutnya diharapkan jam terbang baik latihan semakin tinggi dan dapat menjadi seniman profesional. Termasuk dalam pendampingan adalah kegiatan mempromosikan atau memperkenalkan secara langsung kepada masyarakat sekitar tentang keberadaan kelompok karawitan dengan tujuan mendapatkan job pementasan. Metode pelaksanaan program pengabdian masyarakat ini adalah sebagaimana Gambar 1.

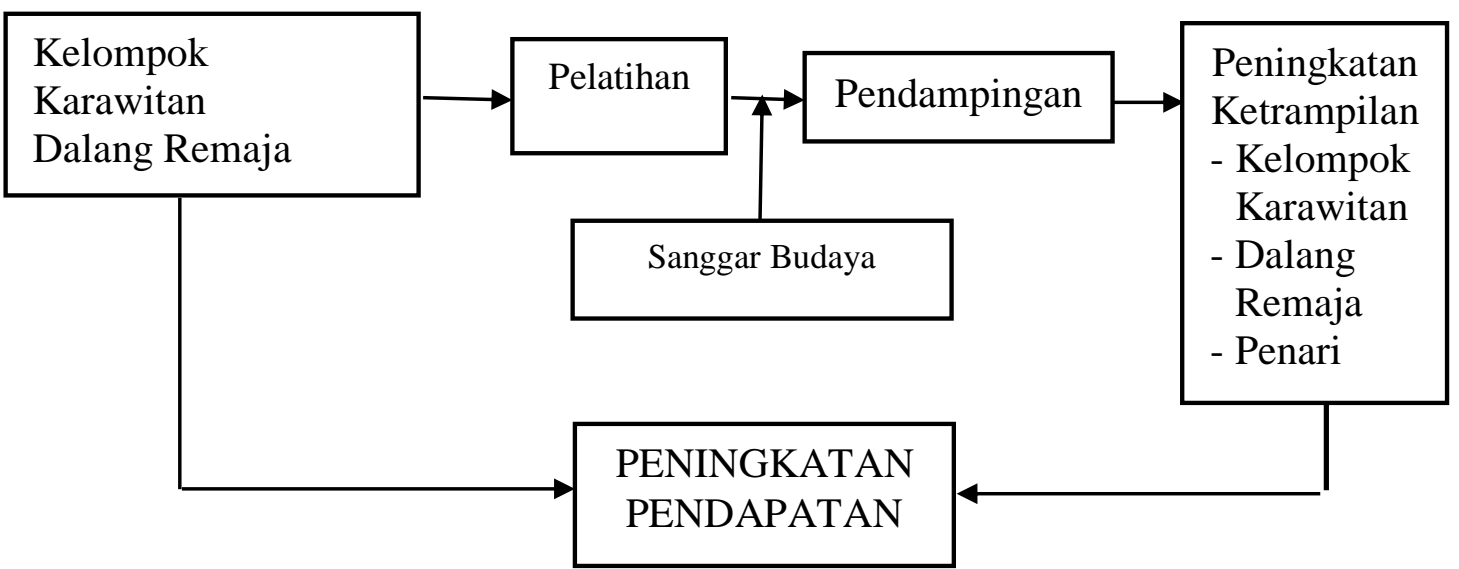

Gambar 1. Metode Pelaksanaan Program Pengabdian Masyarakat

\section{Prosedur Kerja}

Pelaksanaan pengabdian kepada masyarakat ini dilakukan dalam tiga tahap yaitu persiapan, pelaksanaan, dan evaluasi.
Masing-masing tahapan dijelaskan sebagai berikut:

1. Persiapan

Pada tahap persiapan program pengabdian masyarakat ini mencakup 
survey dan sosialisasi. Tahap survey dilaksanakan untuk mengetahui permasalahan mitra dan solusi yang akan dilaksanakan. Tahapan sosialisasi dilaksanakan agar mitra mengetahui maksud, tujuan dan kegiatan yang akan dilaksanakan dalam upaya mengatasi permasalahan mitra.

2. Pelaksanaan

1) Pembentukan Sanggar Budaya

Pembentukan sanggar budaya dilaksanakan berdasarkan diskusi bersama dengan perangkat desa, kelompok karawitan dan masyarakat seni Desa Tahunan.

2) Pelatihan

Setelah dilakukan sosialisasi maka dilaksanakan pelatihan yang mencakup pelatihan karawitan, pedalangan dan seni tari.

3) Pendampingan

Kegiatan pendampingan ditujukan agar rutinitas dan frekuensi latihan tidak menurun. Selain itu dalam pendampingan akan dilakukan kegiatan promosi/ memperkenalkan secara langsung keberadaan kelompok karawitan.

3. Evaluasi

Evaluasi dilaksanakan untuk mengetahui pelaksanaan program pengabdian masyarakat berjalan dengan lancar. Evaluasi dilaksanakan secara menyeluruh terhadap pelaksanaan program dengan melihat hasil akhir yang mencakup rutinitas dan frekuensi latihan, peningkatan ketrampilan pengrawit, dalang dan penari, serta kesempatan pementasan bagi kelompok kesenian.

\section{HASIL}

\section{Pembentukan Sanggar Budaya}

Pembentukan sanggar budaya dilaksanakan berdasarkan kordinasi dengan Pemerintahan Desa Tahunan dan kelompok mitra. Adapun hasil kordinasi adalah:

1) Kelompok mitra menyepakati bahwa bentuk organisasi bukan Sanggar Budaya tetapi berbentuk Kelompok karawitan atau Kelompok Budaya

2) Disepakati bahwa nama kelompok adalah Kelompok Karawitan 'Sumber Laras Irung Petruk'.

3) Termasuk dalam kegiatan Kelompok Karawitan 'Sumber Laras Irung Petruk' adalah kegiatan karawitan, pedalangan dan seni tari.

4) Kelompok Karawitan 'Sumber Laras Irung Petruk' telah sah dan resmi menjadi Kelompok karawitan Desa Tahunan dengan 
diterbitkannya Surat Keputusan

Kepala Desa Tahunan.

5) Adanya penambahan anggota

Kelompok Karawitan yang berasal dari usia SMP dan SMA

\section{Pelatihan}

Pelasaksanaan pelatihan yang meliputi pelatihan karawitan, pedalangan, dan seni tari adalah sebagai berikut:

1) Pelatihan Karawitan

Peserta pelatihan karawitan yang mengikuti program pengabdian kepada masyarakat ini adalah anggota kelompok karawitan di Desa Tahunan sebanyak 15 orang anggota baru terjaring. Sebagian besar mereka masih duduk dibangku sekolah yaitu SMP dan SMA. Pelatihan karawitan dilaksanakan dalam delapan pertemuan. Latihan karawitan tidak dapat dilaksanakan sebagaimana jadwal yang telah ditentukan karena berbagai kesibukan dari anggota kelompok. Tetapi latihan tetap bisa dilaksanakan dua kali dalam seminggu untuk delapan kali pertemuan pada pukul 19.30 s.d. 22.00 WIB.

Materi latihan mencakup srepeg 6, srepeg 9, gending siem, budhalan dan cakilan (mengiringi latihan dalang). Hasil pelatihan menunjukkan ketrampilan dan penguasaan anggota akan gamelan mengalami peningkatan. Materi pelatihan dapat disajikan kembali dengan baik oleh peserta pelatihan. Selain itu apresiasi, pengetahuan dan keterampilan semakin meningkat. Hasil evaluasi menunjukkan bahwa sebagian besar peserta pelatihan sebelumnya belum tahu cara menutup (mithet) dan menabuh yang benar, tetapi setelah mengikuti pelatihan, mereka dapat menabuh gamelan dan menutup dengan benar.

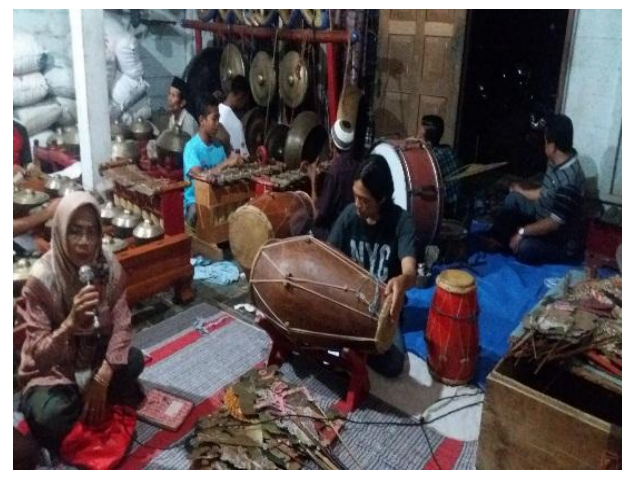

Gambar 2. Kelompok Karawitan 'Sumber Laras Irung Petruk' melakukan latihan rutin

2) Pelatihan Dalang

Dalang remaja yang ada di Desa Tahunan bernama Bima yang masih duduk di bangku SMA dilatih oleh dalang profesional. Jadwal latihan dalang 
menyesuaikan dengan latihan karawitan sebanyak delapan pertemuan pada pukul 19.30 s.d. 22.00. Adapun materi pelatihan dalang adalah mencakup dhodogan, keprak, budhalan, sabet dan cakilan. Selain Bima, terdapat dua remaja lain yang memiliki keinginan untuk belajar pedalangan.

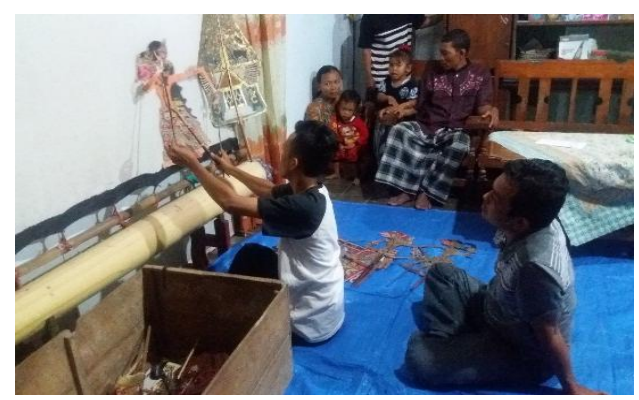

Gambar 3. Suasana Latihan Dalang

Hasil pelatihan menunjukkan ketrampilan dalang remaja dalam ontowecono, suluk, sabet, dhodogan dan keprak dhalang mengalami peningkatan terlihat dari antusiasme penonton saat menyaksikan lakon wayang kulit yang dibawakan Bima.

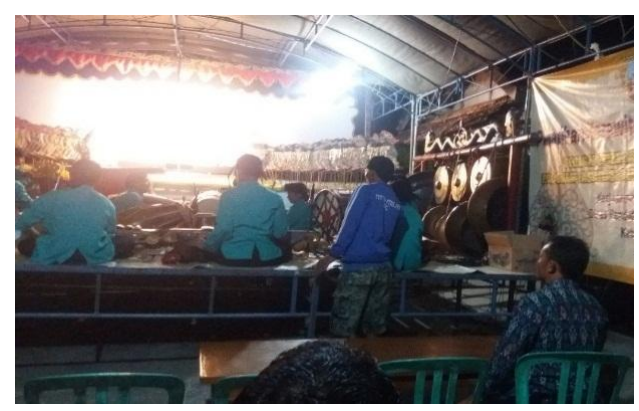

Gambar 4. Pementasan Wayang Kulit
3) Pelatihan Seni tari

Pelatihan seni tari dilaksanakan dalam dua belas pertemuan yang dilaksanakan pada pukul 14.00-16.00 WIB. Peserta latihan tari adalah siswa-siswa SD yang sama sekali belum mengenal dasar tari klasik. Materi tari yang diajarkan adalah Bondan dan tari Gambyong.

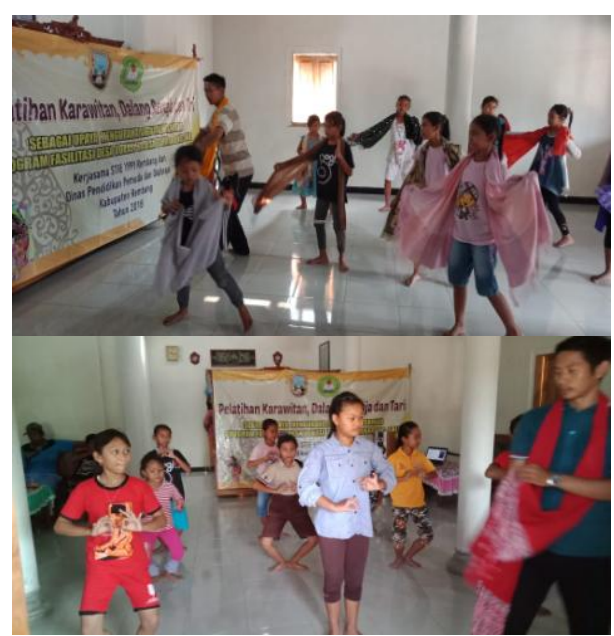

Gambar 5. Latihan Tari Kelompok 'Sumber Laras Irung Petruk'

\section{Pendampingan}

Pendampingan dilaksanakan secara langsung pada saat pelaksanaan latihan. Pada saat latihan pelatih langsung dapat memberikan masukan pada peserta latihan atau mengkoreksi apabila peserta ada yang melakukan kesalahan. Tim pengabdi dalam setiap kesempatan ketika ada kegiatan/acara formal maupun non formal di Desa Tahunan dan sekitarnya ataupun di 
wilayah Kabupaten Rembang selalu menyampaikan tentang keberadaan kelompok karawitan. Promosi secara langsung ini sangat efektif karena masyarakat dapat langsung memberikan respon dengan bertanya tentang kelompok karawitan.

Hasil dari pendampingan adalah:

1) Peserta pelatihan karawitan dapat menyerap materi yang disajikan dengan cukup baik. Di samping itu apresiasi, pengetahuan dan ketrampilan meningkat.

2) Dalang remaja yang ada mampu mengimplementasikan hasil latihan dalam pementasan yang dilakukan

3) Peserta latihan tari dapat memperbaiki gerakan dasar tari klasik.

4) Masyarakat sekitar Desa Tahunan dan sekitarnya sudah mulai mengenal kelompok karawitan.

5) Sudah terdapat beberapa tawaran untuk melakukan pementasan di sekitar Desa Tahunan.

\section{PEMBAHASAN}

Kegiatan pelatihan yang dilaksanakan untuk karawitan, dalang dan seni tari menjadi dasar yang sangat penting sebagai pendorong semangat bagi anggota kelompok agar mampu mandiri berlatih tanpa bergantung pada pelatih. Hal ini dapat diketahui terutama untuk karawitan dan dalang yaitu ketika pelatih sengaja datang terlambat, terlihat peserta pelatihan mampu berlatih materi sebelumnya tanpa bimbingan pelatih.

Pada saat istirahat maka dilakukan diskusi antara pelatih, peserta latihan dan tim pengabdian. Langkah ini ternyata lebih efisien dan efektif karena peserta latihan mendapatkan masukan dan langsung dapat dipraktekkan. Dalam proses pendampingan ini peserta latihan juga dapat menyampaikan masukan dan kesulitan yang dirasakan pada saat latihan. Selain itu dalam kegiatan pendampingan, khususnya pelatih karawitan juga langsung memberikan koreksi pada notnot yang telah ditulis oleh kelompok karawitan. Berkaitan dengan promosi dan pengenalan Kelompok Karawitan, Tim pengabdi merasa perlu untuk membuatkan desain kartu nama dan atau portal sosial media yang dapat digunakan sebagai media promosi Kelompok Karawitan.

Pada evaluasi akhir, Kelompok Karawitan menghendaki adanya keberlanjutan dari pengabdian ini. Hal ini akan dibicarakan lebih lanjut dengan pimpinan kelompok, kepala desa, pada stakeholder dan melakukan pendampingan untuk mengajukan penyusunan proposal pendanaan/hibah 
dari pemerintah Kabupaten Rembang untuk Kelompok Karawitan.

\section{KESIMPULAN}

Berdasarkan hasil program kegiatan pengabdian di Desa Tahunan Kecamatan Sale Kabupaten Rembang ini, dapat disimpulkan bahwa 1) Anggota kelompok menyadari pentingnya peran organisasi dalam memajukan kegiatan kesenian di Desa Sale; 2) Kegiatan pelatihan mampu meningkatkan keterampilan anggota kelompok karawitan, dalang dan seni tari; dan 3) Pendampingan yang dilakukan menghasilkan serapan materi yang diajarkan dapat terjaga. Apresiasi, pengetahuan dan ketrampilan juga meningkat. Dalang remaja yang ada mampu mengimplementasikan hasil latihan dalam pementasan yang dilakukan. Peserta latihan tari dapat memperbaiki gerakan dasar tari klasik. Selain itu, adanya tawaran di sedekah bumi Desa Tahunan dan Desa Gading.

\section{UCAPAN TERIMA KASIH}

Tim pengabdi mengucapkan terima kasih kepada:

1. Drs. Muhammad Asrori, M.Si., Ketua STIE YPPI Rembang dan Anik Nurhidayati, SE., MM., Ketua LPPM STIE YPPI Rembang yang telah memfasilitasi tim pengabdi untuk melakukan pengabdian dan pendampingan di Desa Tahunan.

2. Kepala Desa Tahunan Kec. Sale Kab. Rembang atas izin dan dukungan selama tim pengabdi melakukan pengabdian;

3. Ketua Sanggar Budaya Sumber Laras Irung Petruk Desa Sale yang sangat terbuka untuk masukan dan memberikan usul saran perbaikan yang sesuai dengan karakteristik anggota;

4. Anggota Sanggar Budaya Sumber Laras Irung Petruk Desa Sale yang telah bekerjasama dalam program pengabdian dan menularkan pengaruh yang baik bagi masyarakat desa untuk melestarikan budaya Jawa.

\section{DAFTAR PUSTAKA}

Egar, N., Fahmi, D. A., Yulianti, F., \& Musarokah, S. (2017). Pemberdayaan Remaja Desa Wisata Bendosari Kecamatan Plantungan Kabupaten Kendal Melalui Pelatihan Kepemanduwisataan. Journal of Dedicators Community, 1(2), 150157.

Mawan, I.G. (2016). Pemberdayaan Seni Karawitan Klasik Bagi Generasi Muda. Diakses dari www.isi- 
dps.ac.id/.../pemberdayaan-seni-

kerawitan-klasik-bagi-gen.

Pemerintah Desa Tahunan. 2017. Monografi Desa Tahunan 2017.

Rembang, B. P. S. K. (2015). Rembang Dalam Angka. Kabupaten Rembang: Badan Pusat Statistik Kabupaten Rembang, 3-23.

Sugimin, S. (2009). Pelatihan Karawitan Karang Taruna Dusun Karangrejo Desa Tibayan Kecamatan Jatinom Kabupaten Klaten. Abdi Seni, 1(1).

Sukistono, D. (2014). Pengaruh Karawitan terhadap Totalitas Ekspresi Dalang dalam Pertunjukan Wayang Golek Menak Yogyakarta. Resital: Jurnal Seni Pertunjukan, 15(2), 179-189. https://doi.org/10.24821/resital.v15 i2.852

Supardi, S. (2011). Pelatihan Karawitan Di Grup Karawitan Mojolaras Kelurahan Mojosongo Dan Grup Karawitan Maju Mawas Benowo Ngringo Jaten Karanganyar: Salah Satu Usaha Demi Ketahanan Kehidupan Seni Karawitan Di Era Globalisasi. Abdi Seni, 3(1).

Susilo, Y. S., Soeroso, A., Albizzia, O., Zamroni, M. I., Rofiqoh, Z., Wening, N., ... Megawati, R. (t.t.).
BAPPEDA KOTA YOGYAKARTA. 54.

Tri, H. (2010). Pembinaan Karawitan Kelompok Karawitan Ngesti Laras Paguyuban Ngeksi Gondo Dibawah Naungan Yayasan Adi Budaya Denpasar Tahun 2009. Artikel Bulan April 2010,4, $1-2$ 